\title{
Screening and Characterization of Fibrinolytic Protease Producing Bacillus circulans from Mangrove Sediments Pitchavaram, South East Coast of India
}

\author{
R. Sadeesh Kumar*, R. Rajesh, S. Gokulakrishnan, J. Subramanian \\ Centre of Advanced Study in Marine Biology, Faculty of Marine Sciences, Annamalai University, \\ Parangipettai - 608 502, Tamil Nadu, India \\ *Mobile: 9952798684; Tel: 04144-243223; Fax: 04144-243553
}

*E-mail address: sadeesh86@gmail.com

\begin{abstract}
Regulation and production of Fibrinolytic enzymes from bacterial sources especially from Bacillus strains has taken a leading role in the medical sciences for the treatment of cardiovascular disorders as it removes thrombus or clots adding to its significant role in curing human health issues saving millions. Significant progress has been made during the last few years on the studies of fibrinolytic enzymes in identifying, cloning, purification, characterization and overproduction of these for commercialization in medical sciences and in fields like detergents development. Production of fibrinolytic enzyme from Bacillus circulans was done using Nutrient broth medium. In addition, a strong fibrinolytic enzyme was purified from the cultivation media. The purified enzyme was almost homogeneous with other species of same genus, as examined by SDS-PAGE and sephadex G-75 column chromatography. The enzyme had an optimal $\mathrm{pH}$ of 7-12, an optimal temperature of $50^{\circ} \mathrm{C}$, for fibrin hydrolysis. The molecular mass estimated by gel filtration was 24 to $36 \mathrm{KDa}$. Further studies for characterization and structural elucidation are necessary for their medicinal applications and molecular biological characteristics.
\end{abstract}

Keywords: Bacillus circulans; SDS-PAGE; Chromatography and Fibrinolytic enzyme

\section{INTRODUCTION}

Marine sediments is the richest source for potential microorganisms intended for various pharmaceutical applications including fibrinolytic enzyme production (Kim et al., 2011). Compared to floral system, the microbial population is widely preferred by the researchers owing to their pronounced biochemical diversity, feasibility of mass culture and ease of genetic manipulation (Patel et al., 2005). Among these, marine bacteria which are metabolically more diverse grow faster and easily amenable to genetic manipulations than fungi for better enzyme production.

High molecular weight large plasma fibrinogen (340,000-D) protein consisted of three pairs of disulfide bonded polypeptide $A \alpha, B \beta$, and $\gamma$ Chains composed of 610,461 , and 411 amino acids (Olexa and Budzynski, 1981). It is the precursor of fibrin, which played a major role in blood clot formation during the hemostatic response to tissue injury. It is lysed by plasmin, which is activated from plasminogen by tissue plasminogen activator (Stricker et). 
Therefore the thrombolytic drugs are also called "plasminogen activators" and "fibrinolytic drugs".

Apart from that, the thromboses biological system which maintained the clot formation and fibrinolysis, there is an imbalance between this leads to cause myocardial in fraction all over the world. Basic reasons for blood fail to clot are lack of fibrinogen, vitamin $\mathrm{K}$ deficiency and diminution of anti haemophilic factor V, VII, IX, XI (Vince Jenkins et al., 2012). Now a days, several Chemo therapeutic agents Viz., tissue plasminogen activator, urokinase through intra muscular or orally route was increased to lyses the thrombi or activate active plasmin to degrade fibrin in blood vessels (Tough, 2005; Duffy, 2002). Most widely used fibrinolysis agents are tissue, urokinase and a bacterial type plasminogen type plasminogen activator streptokinase (Collen and Lijnen 2004; Banerjee et al., 2004).

In spite of the benefits of thrombolytic therapy, those had to follow limitation contraindications viz., haemorrhagic stroke, ischemic stroke, central nervous system trauma, gastrointestinal bleeding, aortic dissection, uncontrolled hypertension and refractory resuscitation (Van de Werf et al., 2008; Iyengar and Girish (2011).

Verstraete, (2000) mentioned that the third generation monoteplase, tenecteplase, reteplase, lanoteplase, pamiteplase, and staphylokinase thrombolytic drugs are greater angiographic potency with acute myocardial infarction and bleeding risk might be higher than compared to second generation agents.

Hence the every individual might be aware of choice of therapy, cost effective, easily accessible and affordable. Researchers focused their interest towards the biological sources like Lumbrokinase from earthworm and fibrolase from snake venom for synthesis plasminlike proteins to overcome the side effects caused by commercially available biological agents (Chen et al. 1991; Mihara et al. 1991).

Extracellular proteases s produced by Bacillus species are of main interest from a biotechnological perspective, and are not only in scientific fields of protein chemistry and protein engineering but also in applied fields such as foods and pharmaceutical industries. The genus Bacillus contains a number of industrially important species and approximately half of the present commercial production of bulk enzymes derives from the strains of Bacillus.

In the present study, an attempt has been made to isolate the potent fibrinolytic protease producer and investigate the effect of physical factors like temperature and $\mathrm{pH}$ on protease producing bacteria factors like temperature and $\mathrm{pH}$ on Bacillus circulans isolated from mangrove sediment of Pitchavaram.

\section{MATERIALS AND METHODS}

\section{1. Bacterial culture collection and maintenance}

The bacterial culture Bacillus circulans was procured from sediment of Pitchavaram mangrove sediment (latitude $11^{\circ} 25^{\prime} \mathrm{N}$ and longitude $79^{\circ} 47^{\prime} \mathrm{E}$ ) Tamil Nadu, India. The bacterial culture was maintained in Nutrient Agar Medium and also these organisms were maintained at $4{ }^{\circ} \mathrm{C}$ in slants as a mother culture.

\section{2. Growth studies of Bacillus circulans}

Bacillus circulans was grown in $50 \mathrm{ml}$ of nutrient broth at $37{ }^{\circ} \mathrm{C}$ in a rotary shaker at $120 \mathrm{rpm}$ for $48 \mathrm{hrs}$.

The culture was harvested at every $4 \mathrm{~h}$ interval and its absorbance was read at $540 \mathrm{~nm}$ using a UV-visible spectrophotometer (Deeepvision 1371, India) and Screening for fibrinolytic enzyme-producing microorganisms were carried out. Optimization of different 
parameters for fibrinolytic enzyme production from Bacillus circulans such as effect of $\mathrm{pH}$, carbon sources and nitrogen sources were done.

\section{3. Purification of fibrinolytic enzyme from Bacillus circulans}

\section{3. 1. Ammonium sulfate precipitation}

Solid ammonium sulfate was added to the supernatant containing the fibrinolytic enzyme to make $40 \%$ saturation. This mixture stood overnight at $4{ }^{\circ} \mathrm{C}$ and was centrifuged at $7,000 \mathrm{rpm}$ for $30 \mathrm{~min}$ at $4{ }^{\circ} \mathrm{C}$ to remove particle material. The supernatant was adjusted to 70 $\%$ ammonium sulfate saturation by further addition of solid ammonium sulfate and stayed overnight at $4{ }^{\circ} \mathrm{C}$. The precipitate was collected by centrifugation at $10,000 \mathrm{rpm}$ for $20 \mathrm{~min}$ at $4{ }^{\circ} \mathrm{C}$ for further purification.

\section{3. 2. Dialysis of fibrinolytic enzyme from cultural filtrate of Bacillus circulans}

Dialysis was performed with $14 \mathrm{KD}$ a dialysis tubing. The protein was resuspended in 50 $\mathrm{mM}$ sodiumphosphate $(\mathrm{pH}$ 7.0) and dialyzed (Memra-cel MD 44-14X100CLR) against the same buffer.

\section{3. 3. Purification of fibrinolytic enzyme by Sephadex G-75 chromatograph}

The fibrinolytic enzyme protein in fractions was purified further by chromatography on Sephadex (Sephadex, G-75, Sigma Chemical Co.). Dialyzed fraction was passed through a 10 ml Sephadex column (2.5X60) equilibrated with $10 \mathrm{mM} \mathrm{NaC1} / 5 \mathrm{mM}$ sodium phosphate $(\mathrm{pH}$ 7.0) and washed through with an additional $20 \mathrm{ml}$ of the same buffer.

Contaminating proteins bound to the column were then removed by elution with $50 \mathrm{~m}$ $\mathrm{MNaCl} / 5 \mathrm{mM}$ sodium phosphate ( $\mathrm{pH}$ 7.0). The fibrinolytic enzyme was then eluted with 200 $\mathrm{mM} \mathrm{NaC1/5} \mathrm{mM}$ sodium phosphate ( $\mathrm{pH} 7.0)$.

Fractions $(3 \mathrm{ml})$ were collected and those with an absorbance at $280 \mathrm{~nm}$ greater than 0.7 were combined and purified further by dialysis against the same buffer.

\section{4. Analytical methods}

\section{4. 1. Protein estimation}

The protein content of the culture filtrate was estimated by the dye binding method of Bradford (1976).

\section{4. 2. Reagent}

Coomassie Brilliant Blue G-250 (100 mg) was dissolved in $50 \mathrm{ml}$ of ethanol. To this, $100 \mathrm{ml}$ of $85 \%(\mathrm{v} / \mathrm{v})$ phosphoric acid was added and made up to one later. The concentration in the reagent was $0.01 \%(\mathrm{w} / \mathrm{v})$, CBB G-250, $4.7 \%(\mathrm{v} / \mathrm{v})$, ethanol and $8.5 \%(\mathrm{v} / \mathrm{v})$ phosphoric acid.

\section{4. 3. Procedure}

To $1.0 \mathrm{ml}$ of culture filtrate, $5 \mathrm{ml}$ of CBB was added, mixed thoroughly and read at 595 $\mathrm{nm}$ in a Beckman DU-50 Spectrophotometer. The reagent with sterile un-inoculated medium served as blank. The amount of protein was calculated using Bovine Serum Albumin Fraction (Sigma Chemicals Co., USA) as the standard. 


\section{4. 4. Assay of fibrinolytic Enzymes}

Reaction mixtures containing $0.5 \mathrm{ml}$ of $1 \%$ of either of casein, haemoglobin or fibrin suspension in $0.1 \mathrm{M}$ tris- $\mathrm{HCl}(\mathrm{pH} 8.0)$ and $0.5 \mathrm{ml}$ of Bacterial filtrates were incubated at 37 ${ }^{\circ} \mathrm{C}$ for $30 \mathrm{~min}$. The reaction was terminated by adding $1.0 \mathrm{ml}$ of $0.15 \%$ trichloro acetic acid. Tyrosine was determined in the neat filtrate by measuring the absorbance at570 nm (Egorov et al., 1982). One fibrinolytic enzyme Unit is that amount of enzyme which liberates $1 \mu$ mole of tyrosine in one min. under the assay condition.

\section{4. 5. Sodium Dodecyl Sulphate - Polyacrilamide gel (SDS-PAGE)}

Sodium Dodecyl Sulphate - Polyacrilamide gel (SDS-PAGE) was performed according to the method of Laemmli (1970) with $10 \%(\mathrm{w} / \mathrm{v})$ separating and $5 \%(\mathrm{w} / \mathrm{v})$ stacking gels unless mentioned otherwise. The gel slabs were prepared from stock solutions prepared as detailed below. All stock solutions were prepared in glass distilled water, filtered through Whatman NO.1 filter paper and stored at $4^{\circ} \mathrm{C}$ before use.

\section{RESULTS}

\section{1. Growth kinetics of Bacillus circulans}

Bacillus circulans showed a log phase upto 8, 12, and 16 in nutrient broth respectively. The active log phase extended upto $36 \mathrm{~h}$ in nutrient broth media.

PURE CULTURE IN PETRIDISH ISOLATE

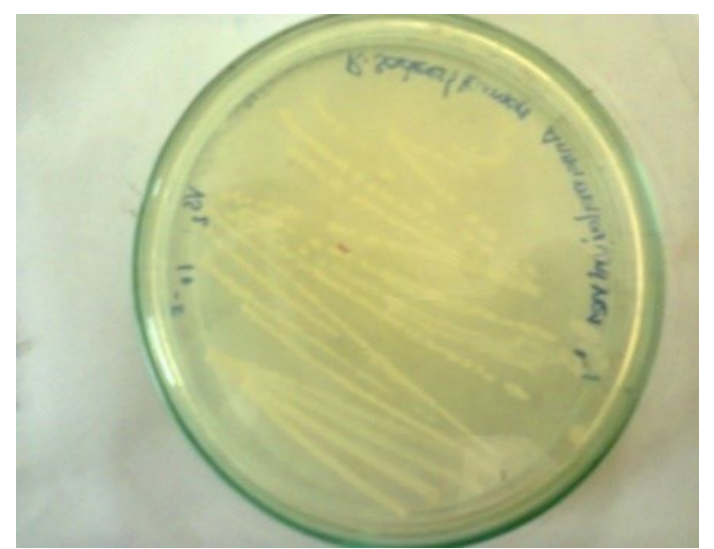

Fig. 1

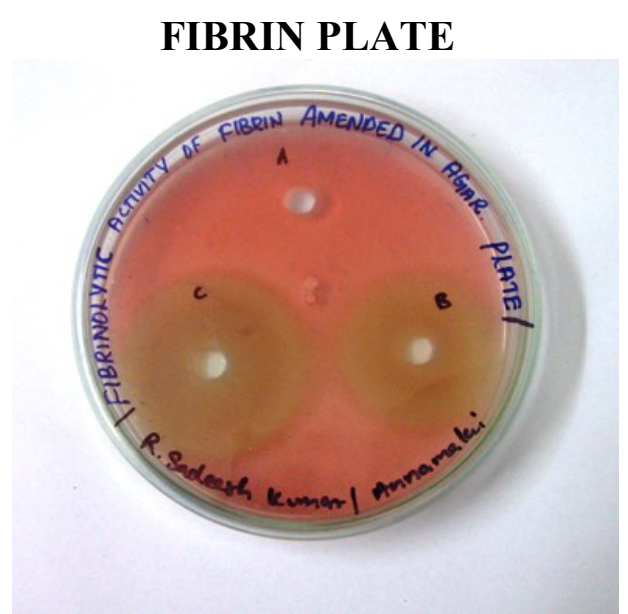

Fig. 2

\section{2. Agar plate screening for fibrinolytic enzyme activity}

Bacillus circulans maximum growth and maximum enzyme production was observed at 48 hours. The zone of hydrolysis of Bacillus circulans on milk agar was analysed. 


\section{3. Optimization of different $\mathrm{pH}$ for the production of fibrinolytic enzyme from Bacillus circulans}

It was evident that the $\mathrm{pH}$ significantly influenced the extracellular protein content and fibrinolytic enzyme activity in Bacillus circulans. The Bacteria was able to release a maximum protein content of $6.4 \mathrm{mg} / \mathrm{ml}$ at $\mathrm{pH} 7.0$ after $36 \mathrm{~h}$ and Fibrinolytic enzyme of 1.74 $\mathrm{U} / \mathrm{ml}$ at $\mathrm{pH} 7.0$ after $36 \mathrm{~h}$.

\section{4. Optimization of different carbon source for the production of fibrinolytic enzyme from Bacillus circulans}

Four different carbon sources such as Glucose, Fructose, maltose, dextrin and sucrose were tested for Fibrinolytic enzyme production in Bacillus circulans. Among the carbon $36 \mathrm{~h}$ and Fibrinolytic enzyme of $1.74 \mathrm{U} / \mathrm{ml}$ at $\mathrm{pH} 7.0$ after $36 \mathrm{~h}$ sources; Fructose supported a maximum Fibrinolytic activity of $1.8 \mathrm{U} / \mathrm{ml}$ with a highest extracellular protein of $6.5 \mathrm{mg} / \mathrm{ml}$ at $36 \mathrm{~h}$.

\section{5. Production of different nitrogen source for the production of fibrinolytic enzyme from Bacillus circulans}

Five different nitrogen sources such as Sodium Nitrate, Ammonium Nitrate, Ammonium sulphate and Ammonium Nitrate were tested for extracellular protein and Fibrinolytic enzyme production in Bacillus circulans. Among them ammonium Nitrate supported a maximum extracellular protein content of $6 \mathrm{mg} / \mathrm{ml}$ at $36 \mathrm{~h}$ and Fibrinolytic enzyme production of $1.5 \mathrm{U} / \mathrm{ml}$ at $36 \mathrm{~h}$.

\section{PRODUCTION OF FIBRINOLYTIC ENZYME}

\section{COLUMN PURIFICATION}

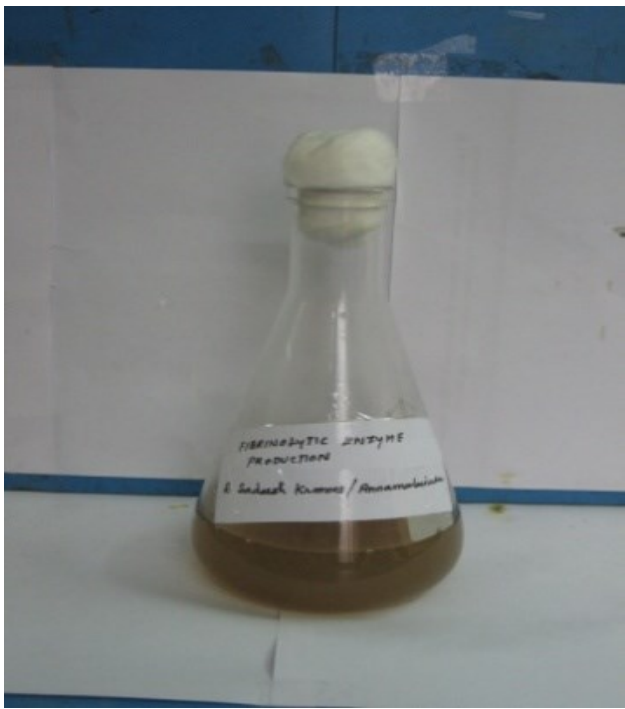

Fig. 3

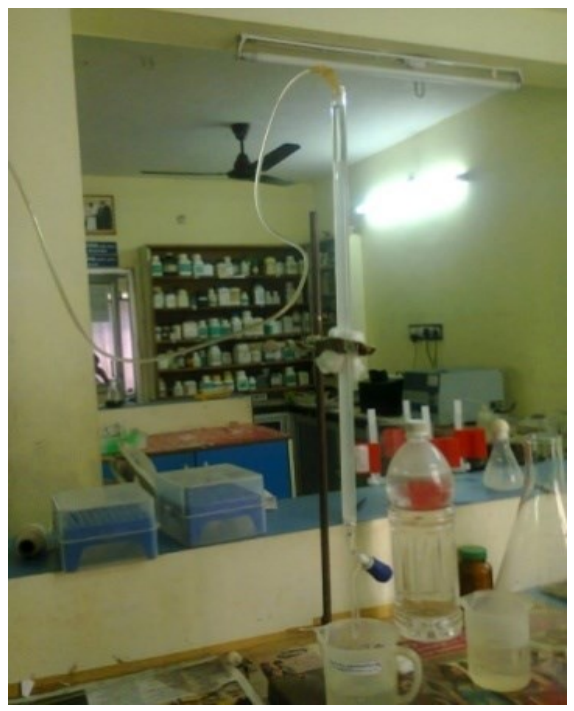

Fig. 4

\section{6. Purification of fibrinolytic enzyme from Bacillus circulans}

The cell free extract of Bacillus circulans was collected after extraction with sodium phosphate buffer and its proteins were precipitated by salting out with ammonium sulfate (70\%). The crude protein preparation was dialyzed, concentrated by lyophilisation and used 
for further analysis. The flow chart for the purification homogeneity of Fibrinolytic enzyme is presented.

\section{DISCUSSION AND CONCLUSION}

Fibrinolytic enzymes have been isolated and characterized from various organisms, and it is known that snake venomsare the most abundant sources. There were relatively fewer reports on the enzymes from plant. In a survey with the crude extracts, recently found that marine organisms, including a species of marine algae, also had fibrinolytic activity.

The present investigation maximum production of the enzyme by was at a $\mathrm{pH}$ range of 3-8 with an optimum of $\mathrm{pH}$ 7.0. Among the different carbon sources used for production of the fibrinolytic enzyme from the Bacillus circulans, Fructose was recommended and this strain could utilize Ammonium nitrate, sodium acetate, glycerol-arginine, fructose, mannose and arabinose to produce enzyme in the range of $60-70 \%$ of the optimum but utilization of dextrin, rhamnose and lactose could only $40 \%$ enzyme.

\section{References}

[1] Couto LT, Donato JL, de Nucci G., Braz J Med Biol Res 37 (2004) 1889-1894.

[2] Daginawala, HF., Prasad, S., Kashyap, RS., Deopujari, JY., Purohit, HJ. and Taori, GM., Thrombosis Journal 4 (2006) 14.

[3] Gupta R., Beeg Q., Khan S., Chauhan B., Appl Microbiol Biotechnol 60(4) (2002) 381-395.

[4] Gupta R., Beeg Q., Loranz P., Appl Microbiol Biotechnol 59(1) (2002) 15-32.

[5] Fujita M, Nomura K, Hong K, Ito Y, Asada A., Nishimuro S., Biochem Biophys Res Commun 197 (1993) 1340-1347.

[6] Fitzpatrick L.R., Small J.S., Greene W.H., Karpa K.D., Keller D., Gut Pathogens 3 (2011) 1-9.

[7] Ha Y.M., Park Y.H., Kim Y.J.. Molecular Biology Today 3 (2002) 25-29.

[8] Jeong YK, Yang WS, Kim KH, Chung KT, Loo WH and Park JU., Biotechnol Lett. 26 (2004) 393-397.

[9] Kim J.Y., Gum S.N., Paik J.K., Lim H.H., Kim K.C., Ogasawara K., Inoue K., Park S., Hypertension Research 31 (2008) 15831588.

[10] Leonardi A., Gubensek F., Krizaj I., Toxicon 40 (2002) 55-62.

[11] Olexa SA, Budzynski AZ., J Biol Chem 256 (1981) 3544-3549, Blood. 68(1) (1986) 275-280.

[12] Shin H., Bandara N., Shin E., Ryu S., Kim K.P., Res Microbiol. 162 (2011) 791-797.

[13] Sharma S, Aneja MK, Mayer J, Scholter M and Munch JC., Fems Microbiol Lett 240 (2004) 181-186. 
[14] Sumi H., Nakajima N., Yatagai C., Comp Biochem Physiol Biochem Mol Biol 112 (1995) 543-547.

[15] Stricker RB, Wong D, Shiu DT, Reyes PT, Shuman MA., Blood. 68(1) (1986) 2752-80.

[16] Tough J., Nurs Stand 19(37) (2005) 55-56.

[17] Tsuchida-Straeten N, Ensslen S, Schafer C, Woltje M, Denecke B, Moser M, Graber S, Wakabayashi S, Koide T, Jahnen-Dechent W., J Thromb Haemost 3(5) (2005) 865-872.

[18] Verstraete M., Am J Med. 109(1) (2000) 52-58.

[19] Vince Jenkins P., Orla Rawley, Owen P. Smith and James S. O'Donnell, British Journal of Haematology 157(6) (2012) 653-663.

[20] Wei X., Luo, M. Xu, L., Zhang Y., Lin X., Kong P., Liu H., J. Agric. Food Chem. 59 (2011) 3957-3963.

[21] Wong AH., Mine Y., J Agric Food Chem 52 (2004) 980-986.

[22] Yamashita T., Oda E., Giddings J.C., Yamamoto J., Pathophysiol Haemost Thromb. 33 (2003) 138-143.

[23] Yossan S., Reungsang A., Yasuda M., Science Asia 32 (2006) 379-385. 